Buletin Ilmiah Math. Stat. dan Terapannya (Bimaster)

Volume 08, No. 3 (2019), hal 437 - 446

\title{
METODE MAXIMUM LIKELIHOOD DALAM PENAKSIRAN MODEL SPATIAL AUTOREGRESSIVE \\ (Studi Kasus: Indeks Pembangunan Manusia Seluruh Provinsi di Indonesia pada Tahun 2016)
}

\author{
Henny Priandini Amalia, Yundari , Helmi
}

\begin{abstract}
INTISARI
Indeks Pembangunan Manusia (IPM) adalah suatu indikator tingkat kualitas hidup manusia melalui berbagai faktor yang mempengaruhi. Pembangunan manusia terus mengalami kemajuan seiring dengan meningkatnya Indeks Pembangunan Manusia (IPM). Data IPM setiap tahunnya pasti berbeda-beda, hal ini memungkinkan adanya saling ketergantungan dari faktor-faktor yang mempengaruhi IPM dengan terjadinya korelasi antardaerah. Permasalahan ini dapat dimodelkan dalam bentuk pemodelan spasial. Salah satu pemodelan spasial adalah model Spatial Autoregressive (SAR). Pada penelitian ini dilakukan pemodelan SAR dengan tujuan untuk menganalisis adanya dependensi spasial dari beberapa lokasi dan pengaruh faktor-faktor dari suatu variabel independen. Pada estimasi model SAR digunakan metode Maximum Likelihood dan diterapkan pada kasus IPM seluruh provinsi di Indonesia pada tahun 2016. Hasil penelitian diperoleh bahwa terdapat dependensi lag spasial antarprovinsi yang berarti provinsi yang berdekatan memiliki nilai yang cenderung mirip. Uji dependensi spasial dilakukanpada matriks pembobot dengan metode queen contiguity dan diperoleh nilai p-value signifikan pada 5\%. Hal ini menunjukkan bahwa terdapat dependensi spasial antarprovinsi. Berdasarkan model yang telah diperoleh untuk masingmasing tetangga, disimpulkan bahwa semak in banyak jumlah tetangga sangat berpengaruh terhadap nilai estimasi persentase indeks pembangunan manusia seluruh provinsi di Indonesia pada tahun 2016.
\end{abstract}

Kata Kunci : Regresi Spasial, Dependensi Spasial, IPM, Spatial Autoregressive.

\section{PENDAHULUAN}

Indeks pembangunan manusia (IPM) adalah suatu indikator tingkat kualitas hidup manusia melalui 5 komponen dasar dengan faktor yang mempengaruhi pada bidang kesehatan, pendidikan, pemukiman, dan tenaga kerja. Pembangunan manusia di Indonesia terus mengalami kemajuan sehingga berakibat meningkatnya IPM Indonesia. Menurut BPS (2016) untuk IPM Indonesia telah mencapai 70,18\% meningkat sebesar 0,63 poin dibandingkan tahun sebelumnya [1]. Hal ini berarti IPM di Indonesia meningkat 0,9\% pada periode 2015-2016 [1]. IPM tertinggi di Indonesia dicapai oleh Provinsi DKI Jakarta dengan IPM sebesar 70,96\%, sedangkan pencapaian terendah adalah Provinsi Papua dengan IPM sebesar 58,05\%. Pencapaian pembangunan manusia pada tingkat regional cukup bervariasi [1]. Hal ini dimungkinkan karena terdapat saling ketergantungan dari faktor yang mempengaruhi IPM dan korelasi antarwilayah. Berdasarkan data IPM dan faktor yang mempengaruhi maka masalah ini dapat dimodelkan dalam bentuk analisis regresi spasial.

Analisis regresi adalah studi mengenai ketergantungan variabel dependen dengan satu atau lebih variabel independen yang diketahui [2]. Metode analisis yang digunakan pada penelitian ini adalah regresi spasial karena data yang dianalisis berhubungan dengan letak geografis suatu wilayah. Regresi spasial adalah hasil pengembangan dari regresi linear sederhana. Pengembangan tersebut berdasarkan terdapat pengaruh tempat atau spasial pada data yang dianalisis. Data spasial merupakan data pengukuran yang memuat suatu informasi lokasi. Berdasarkan tipe data, pemodelan spasial dapat dibedakan menjadi pemodelan dengan pendekatan titik dan area. Penelitian ini menggunakan pendekatan area karena berdasarkan prinsip pendekatan (contiguity) antarwilayah. Pendekatan ini menunjukkan terdapat dependensi lag spasial antarlokasi. 
Terdapat informasi hubungan spasial antarwilayah menyebabkan perlu adanya keragaman spasial ke dalam model, sehingga model yang digunakan adalah model regresi spasial. Beberapa model yang telah berkembang adalah Spatial Autoregressive Model (SAR), Spatial Error Model (SEM), dan Spatial Autoregressive Moving Average (SARMA) [3].

Pemodelan spasial yang digunakan dalam penelitian ini adalah model Spatial Autoregressive (SAR), karena pemodelan ini sesuai dengan pola spasial dengan pendekatan area. Pendekatan area yaitu pendekatan berdasarkan prinsip pendekatan (contiguity) antarwilayah. Model SAR ini menggunakan data spasial area sebagai pendekatan antarwilayah. Matriks pembobot yang digunakan adalah matriks berdasarkan pada persinggungan antar lokasi yang diamati yaitu matriks contiguity [4]. Estimasi mode1 SAR menggunakan metode Maximum Likelihood yang dapat diaplikasikan pada data IPM seluruh provinsi di Indonesia pada tahun 2016.

Penelitian ini diawali dengan identifikasi data yang terdiri dari variabel dependen dan variabel independen ke dalam peta tematik provinsi di Indonesia. Kemudian pendeskripsian data persentase IPM dengan peta tematik. Kemudian dilakukan penentuan matriks bobot untuk setiap provinsi dengan matriks queen contiguity. Kemudian uji autokorelasi spasial dilakukan pada setiap variabel dengan menggunakan Moran's I berdasarkan nilai pembobot yang sudah diketahui masing-masing wilayah. Tahapan untuk uji autokorelasi pada model regresi spasial dilakukan dengan langkah memeriksa dari model regresi klasik melalui uji normalitas dan uji heterokedastisitas. Pada proses estimasi parameter model SAR digunakan metode maximum likelihood.

Kemudian dilakukan pemodelan OLS yang terdiri dari estimasi parameter pada variabel independen terhadap variabel dependen serta uji signifikansi estimasi parameter. Uji signifikansi estimasi parameter dilakukan untuk melihat dependensi lag spasial pada variabel dependen maupun variabel independen, kemudian dilakukan uji hipotesis signifikansi parameter. Setelah diperoleh model SAR dengan kriteria nilai AIC yang paling kecil dan nilai $\mathrm{R}^{2}$ terbesar, langkah terakhir adalah menginterpretasikan dan menyimpulkan hasil analisis model SAR.

\section{REGRESI LINEAR BERGANDA}

Regresi linear berganda adalah persamaan regresi yang mempunyai lebih dari satu variabel independen, model ini dikembangkan untuk mengestimasikan nilai variabel dependen dengan menggunakan lebih dari satu variabel independen [2]. Bentuk umum dari sebuah model regresi berganda untuk $k$ variabel independen diberikan oleh:

$$
\mathbf{Y}=\boldsymbol{\beta}_{0}+\boldsymbol{\beta}_{1} \mathbf{X}_{1}+\boldsymbol{\beta}_{2} \mathbf{X}_{2}+\ldots+\boldsymbol{\beta}_{\mathbf{k}} \mathbf{X}_{\mathbf{k}}+\varepsilon
$$

Variabel $\boldsymbol{\varepsilon}$ merupakan variabel acak error, parameter $\boldsymbol{\beta}_{\mathbf{0}}, \boldsymbol{\beta}_{1}, \boldsymbol{\beta}_{2}, \ldots, \boldsymbol{\beta}_{\mathbf{k}}$ adalah koefisien-koefisien regresi yang diestimasi. Variabel $\mathbf{X}_{\mathbf{1}}, \mathbf{X}_{\mathbf{2}}, \ldots, \mathbf{X}_{\mathbf{k}}$ sebagai variabel independen yang linear [5].

\section{MATRIKS PEMBOBOT SPASIAL}

Matriks pembobot spasial merupakan matriks yang menyatakan hubungan dari wilayah pengamatan yang berukuran $n \times n$ dan disimbolkan dengan W. Matriks pembobot spasial ini bersifat simetri dengan diagonal utamanya bernilai 0 . Matriks pembobot spasial digunakan untuk menentukan bobot antarlokasi yang diamati berdasarkan hubungan ketetanggaan antarlokasi. Matriks pembobot spasial dinotasikan dengan $\mathbf{W}$ yang berukuran $n \times n$ dimana $\mathrm{n}$ merupakan jumlah data yang diteliti. Elemen diagonal pada matriks pembobot $\mathbf{W}$ diberi bobot 0 [6],

$$
\mathrm{W}_{\mathrm{ij}}=\left\{\begin{array}{l}
\mathbf{1} \text { jika i dan } \mathrm{j} \text { saling bertetanggaan } \\
\mathbf{0} \text { untuk yang tidak bertetanggaan }
\end{array} .\right.
$$


Salah satu metode penentuan matriks pembobot yang digunakan dalam penelitian ini adalah persinggungan sisi-sudut (queen contiguity). Matriks pembobot $\mathbf{W}$ dengan elemen $\mathrm{w}_{\mathrm{ij}}$ berukuran $n \times n$, dengan setiap elemen matriks menggambarkan ukuran kedekatan antara pengamatan ke $i$ dan $j$. Elemen matriks didefinisikan 1 untuk wilayah yang bersisian (common side) atau titik sudut (common vertex) dengan daerah yang menjadi titk acuan, sedangkan yang lainnya didefinisikan elemen matriks pembobot dengan 0. Ilustrasi disajikan ada Gambar 1 [7].

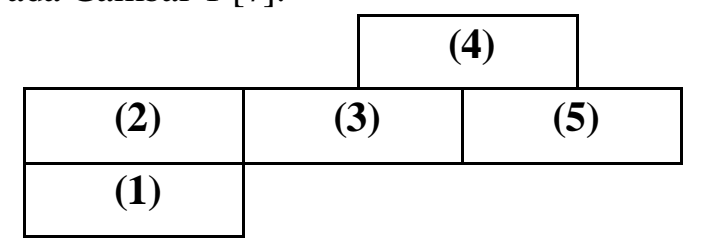

Gambar 1 Ilustrasi Contiguity

Matriks pembobot yang dapat terbentuk dari Gambar 1 sebagai berikut.

$$
\mathrm{W}_{\text {Queen }}=\left[\begin{array}{lllll}
\mathrm{W}_{11} & \mathrm{~W}_{12} & \mathrm{~W}_{13} & \mathrm{~W}_{14} & \mathrm{~W}_{15} \\
\mathrm{~W}_{21} & \mathrm{~W}_{22} & \mathrm{~W}_{23} & \mathrm{~W}_{24} & \mathrm{~W}_{25} \\
\mathrm{~W}_{31} & \mathrm{~W}_{32} & \mathrm{~W}_{33} & \mathrm{~W}_{34} & \mathrm{~W}_{35} \\
\mathrm{~W}_{41} & \mathrm{~W}_{42} & \mathrm{~W}_{43} & \mathrm{~W}_{44} & \mathrm{~W}_{45} \\
\mathrm{~W}_{51} & \mathrm{~W}_{52} & \mathrm{~W}_{53} & \mathrm{~W}_{54} & \mathrm{~W}_{55}
\end{array}\right]=\left[\begin{array}{lllll}
0 & 1 & 1 & 0 & 0 \\
1 & 0 & 1 & 0 & 0 \\
1 & 1 & 0 & 1 & 1 \\
0 & 0 & 1 & 0 & 1 \\
0 & 0 & 1 & 1 & 0
\end{array}\right]
$$

Baris dan kolom pada matriks menyatakan wilayah berdasarkan pada Gambar 1 setelah memperoleh matriks Queen Contiguity, kemudian dilakukan standarisasi pada masing-masing entri untuk mendapatkan jumlah baris sama dengan satu. Rumus untuk standarisasi matriks pembobot Queen Contiguity dapat dituliskan sebagai berikut [8]:

$$
\mathrm{w}_{\mathrm{ij}}=\frac{\mathrm{c}_{\mathrm{ij}}}{\mathrm{c}_{\mathrm{i}}}
$$

dengan $c_{i .}=\sum_{j=1}^{n} c_{i j}$ dan $c_{i j}=$ Nilai pada baris ke $i$ kolom ke $j$. Sehingga diperoleh matriks pembobot Queen Contiguity terstandarisasi sebagai berikut:

$$
\mathbf{W}_{\mathbf{1}}=\left[\begin{array}{ccccc}
0 & 1 / 2 & 1 / 2 & 0 & 0 \\
1 / 2 & 0 & 1 / 2 & 0 & 0 \\
1 / 4 & 1 / 4 & 0 & 1 / 4 & 1 / 4 \\
0 & 0 & 1 / 2 & 0 & 1 / 2 \\
0 & 0 & 1 / 2 & 1 / 2 & 0
\end{array}\right]
$$

\section{UJI MORAN'S I}

Dependensi spasial terjadi akibat adanya dependensi dalam data wilayah berdasarkan hukum Tobler yaitu segala sesuatu yang saling berhubungan dengan yang lain, tetapi sesuatu yang lebih dekat lebih memberikan pengaruh dibandingkan dengan yang jauh. Terdapat dependensi spasial mengindikasikan bahwa nilai atribut pada daerah tertentu terkait oleh nilai atribut daerah lain yang letaknya berdekatan atau bertetanggaan. Indeks Moran's adalah ukuran dari korelasi (hubungan) antara pengamatan yang saling berdekatan [9]. Moran's I dapat diukur dengan menggunakan persamaan [10].

Hipotesis yang digunakan adalah:

$H_{0}: I=0$ (tidak ada autokorelasi antar lokasi)

$H_{1}: I \neq 0$ (ada autokorelasi antar lokasi)

$$
I=\frac{\sum_{\mathrm{i}=1}^{\mathrm{n}} \sum_{\mathrm{j}=1}^{\mathrm{n}} \mathrm{w}_{\mathrm{ij}}\left(\mathrm{x}_{\mathrm{i}}-\overline{\mathrm{x}}\right)\left(\mathrm{x}_{\mathrm{j}}-\overline{\mathrm{x}}\right)}{\sum_{\mathrm{i}=1}^{\mathrm{n}} \sum_{\mathrm{j}=1}^{\mathrm{n}} \mathrm{w}_{\mathrm{ij}}\left(\sum_{\mathrm{i}=1}^{\mathrm{n}}\left(\mathrm{x}_{\mathrm{i}}-\overline{\mathrm{x}}\right)^{2}\right)} .
$$

Nilai I sama dengan koefisien korelasi yaitu diantara -1 sampai 1. Sehingga untuk mengatakan terdapat autokorelasi perlu dibandingkan dengan nilai statistik $I$ dengan nilai harapan. Statistik uji yang digunakan, yaitu: 
dengan,

$$
Z_{\text {hitung }}=\frac{I-\mathrm{E}(I)}{\sqrt{\operatorname{Var}(I)}} \sim N(0,1),
$$

$$
\operatorname{Var}(I)=\frac{n^{2} S_{1}-n S_{2}+3 S_{0}{ }^{2}}{\left(n^{2}-1\right) S_{0}{ }^{2}}, S_{0}=\sum_{i=1}^{n} \sum_{j=1}^{n} w_{i j}, S_{1}=\frac{1}{2} \sum_{i \neq j}^{n}\left(w_{i j}+w_{j i}\right)^{2}, S_{2}=\sum_{i=1}^{n}\left(\sum_{j=1}^{n} w_{i j}+\sum_{j=1}^{n} w_{j i}\right)^{2}
$$

Nilai ekspektasi dari Moran's I adalah,

$$
\mathrm{E}(I)=I_{0}=-\frac{1}{n-1}
$$

Pengambilan keputusan adalah $H_{0}$ ditolak jika $\left|Z_{\text {hitung }}\right|>Z \alpha / 2$. Nilai dari indeks $I$ adalah antara -1 dan 1. Jika $I>I_{0}$, maka data berautokorelasi positif $I<I_{0}$ artinya data berautokorelasi negatif.

\section{UJI LANGRANGE MULTIPLIER (LM)}

Uji LM digunakan untuk menentukan adanya efek spasial atau tidak di dalam model. Bentuk hipotesis LM untuk pemodelan SAR, yaitu [11]:

Hipotesis yang digunakan adalah:

$H_{0}: \rho=0$ (tidak ada efek spasial pada lag)

$H_{0}: \rho \neq 0$ (ada efek spasial pada lag)

$$
L M_{l a g}=\frac{\left(\boldsymbol{\varepsilon}^{\mathbf{T}} \mathbf{W Y}\right)^{2}}{\mathrm{~s}^{2}\left((\mathbf{W X} \boldsymbol{\beta})^{\mathbf{T}} \mathbf{M}(\mathbf{W X} \boldsymbol{\beta})+\mathrm{Ts}^{2}\right)^{\prime}}
$$

dengan,

$$
\mathbf{M}=\mathbf{I}-\mathbf{X}\left(\mathbf{X}^{\mathbf{T}} \mathbf{X}\right)^{-1} \mathbf{X}^{\mathbf{T}}, \mathrm{T}=\operatorname{tr}\left[\left(\mathbf{W}^{\mathbf{T}}+\mathbf{W}\right) \mathbf{W}\right], \mathrm{s}^{2}=\frac{\boldsymbol{\varepsilon}^{\mathbf{T}} \boldsymbol{\varepsilon}}{\mathrm{n}} .
$$

Pengambilan keputusan, tolak $H_{0}$ jika $L M_{\text {lag }}>\chi_{(1,1-\alpha)}^{2}$. Jika $L M_{\text {lag }}$ signifikan maka model yang sesuai adalah SAR.

\section{UJI SIGNIFIKANSI PARAMETER}

Pengujian signifikansi parameter pemodelan spasial pada penelitian ini menggunakan uji Wald [9]. Pengujian terhadap parameter model dilakukan untuk mengetahui peranan variabel independen dalam model. Pengujian parameter $\rho$ digunakan hipotesis sebagai berikut [12]:

Statistik uji yang digunakan pada persamaan:

$$
\begin{aligned}
& H_{0}: \rho=0 \\
& H_{1}: \rho \neq 0
\end{aligned}
$$

$$
\operatorname{Wald}_{\rho}=\frac{\hat{\rho}^{2}}{\operatorname{Var}(\hat{\rho})}
$$

Untuk menguji parameter $\beta$ menggunakan hipotesis sebagai berikut:

dengan statistik uji

$$
\begin{aligned}
& H_{0}: \beta_{j}=0 \\
& H_{1}: \beta_{j} \neq 0, j=1,2, \ldots, k
\end{aligned}
$$

$$
\operatorname{Wald}_{\beta}=\frac{\widehat{\beta}_{j}^{2}}{\operatorname{Var}\left(\widehat{\beta_{j}}\right)}
$$

dengan,

$\operatorname{Var}(\hat{\rho})$ : varians estimasi parameter $\rho$

$\operatorname{Var}\left(\widehat{\beta_{j}}\right)$ : varians estimasi parameter $\beta$

Kriteria pengambilan keputusan adalah dengan $H_{0}$ ditolak jika nilai Wald $>\chi_{a, 1}^{2}$. 


\section{MODEL SPATIAL AUTOREGRESSIVE (SAR)}

SAR adalah model yang mengkombinasikan model regresi sederhana dengan lag spasial pada variabel dependen dengan menggunakan data cross section. Spatial Autoregressive Model dapat dituliskan dengan [13],

dengan,

$$
\mathbf{Y}=\rho \mathbf{W Y}+\mathbf{X} \boldsymbol{\beta}+\boldsymbol{\varepsilon}, \quad \boldsymbol{\varepsilon} \sim \mathrm{N}\left(0, \sigma^{2} \mathbf{I}\right)
$$

$\mathbf{Y}=$ vektor variabel dependen $n \times 1$

$\mathbf{X}=$ matriks variabel independen $(n \times(\mathrm{k}+1))$

$\boldsymbol{\beta}=$ vektor koefisien parameter regresi $(\mathrm{k}+1) \times 1)$

$\rho=$ parameter koefisien lag spasial variabel independen

$\mathbf{W}=$ matriks pembobot dengan ukuran $n \times n$

$\boldsymbol{\varepsilon}=$ vektor error dengan ukuran $n \times 1$

$\mathbf{I}=$ matriks identitas dengan ukuran $n \times n$

$\mathrm{N}=$ jumlah amatan atau lokasi

Kelebihan dari model SAR adalah model tepat digunakan untuk pola spasial dengan pendekatan area.

\section{METODE MAXIMUM LIKELIHOOD}

Untuk mengetahui model SAR ini konsisten, maka adanya pengembangan model estimasi parameter dengan estimasi maksimum likelihood.

Pembentukan fungsi likelihood dapat dilakukan melalui error $\boldsymbol{\varepsilon}$ dari model SAR berikut,

$$
\begin{gathered}
\mathbf{Y}=\rho \mathbf{W Y}+\mathbf{X} \boldsymbol{\beta}+\boldsymbol{\varepsilon}, \\
\boldsymbol{\varepsilon} \sim \mathrm{N}\left(0, \sigma^{2} \mathbf{I}\right) .
\end{gathered}
$$

Selanjutnya fungsi kepadatan peluang bersama yang digunakan adalah sebagai berikut:

$$
f(\mathbf{Y})=\left(\frac{1}{2 \pi \sigma^{2}}\right)^{n / 2} \exp \left[-\frac{((\mathbf{I}-\rho \mathbf{W}) \mathbf{Y}-\mathbf{X} \boldsymbol{\beta})^{\mathbf{T}}((\mathbf{I}-\rho \mathbf{W}) \mathbf{Y}-\mathbf{X} \boldsymbol{\beta})}{2 \sigma^{2}}\right] .
$$

Adapun fungsi likelihood variabel dependen $\mathbf{Y}$ adalah

$\mathrm{L}\left(\boldsymbol{\beta}, \rho, \sigma^{2} ; \mathbf{Y}\right)=\mathrm{f}\left(\mathbf{Y} ; \boldsymbol{\beta}, \rho, \sigma^{2}\right)$

$$
=\left(\frac{1}{2 \pi \sigma^{2}}\right)^{\mathrm{n} / 2} \exp \left[-\frac{((\mathbf{I}-\rho \mathbf{W}) \mathbf{Y}-\mathbf{X} \boldsymbol{\beta})^{\mathbf{T}}((\mathbf{I}-\rho \mathbf{W}) \mathbf{Y}-\mathbf{X} \boldsymbol{\beta})}{2 \sigma^{2}}\right] .
$$

Selanjutnya diperoleh fungsi log likelihood sebagai berikut:

$$
\ln L=-\frac{n}{2} \ln 2 \pi-\frac{n}{2} \ln \sigma^{2}-\frac{((\mathbf{I}-\rho \mathbf{W}) \mathbf{Y}-\mathbf{X} \boldsymbol{\beta})^{\mathbf{T}}((\mathbf{I}-\rho \mathbf{W}) \mathbf{Y}-\mathbf{X} \boldsymbol{\beta})}{2 \sigma^{2}} .
$$

Estimasi parameter $\sigma^{2}, \boldsymbol{\beta}$, dan $\rho$ diperoleh dengan memaksimumkan fungsi log likelihood yaitu, Estimasi parameter $\sigma^{2}$

$$
\widehat{\sigma^{2}}=\frac{((\mathbf{I}-\rho \mathbf{W}) \mathbf{Y}-\mathbf{X} \boldsymbol{\beta})^{\mathbf{T}}((\mathbf{I}-\rho \mathbf{W}) \mathbf{Y}-\mathbf{X} \boldsymbol{\beta})}{\mathrm{n}},
$$

estimasi parameter $\boldsymbol{\beta}$

$$
\widehat{\boldsymbol{\beta}}=\left(\mathbf{X}^{\mathbf{T}} \mathbf{X}\right)^{-1} \mathbf{X}^{\mathbf{T}}(\mathbf{I}-\rho \mathbf{W}) \mathbf{Y} \text {, dan }
$$

estimasi parameter $\rho$ menggunakan fungsi logaritma natural

$$
\begin{gathered}
f(c)=c-\frac{n}{2} \ln \left(\left(\mathbf{e}_{\mathbf{0}}-\rho \mathbf{e}_{\mathbf{d}}\right)^{\mathbf{T}}\left(\mathbf{e}_{\mathbf{0}}-\rho \mathbf{e}_{\mathbf{d}}\right)\right), \quad \mathrm{c}=-\frac{\mathrm{n}}{2} \ln (2 \pi)-\frac{\mathrm{n}}{2} \ln (\mathrm{n})-\frac{1}{2} . \\
\mathbf{e}_{\mathbf{0}}=\mathbf{y}-\mathbf{X} \boldsymbol{\delta}_{\mathbf{0}}, \quad \mathbf{e}_{\mathbf{d}}=\mathbf{W} \mathbf{y}-\boldsymbol{\delta}_{\mathbf{d}}, \quad \boldsymbol{\delta}_{\mathbf{0}}=\left(\mathbf{X}^{\mathbf{T}} \mathbf{X}\right)^{-\mathbf{1}} \mathbf{X}^{\mathbf{T}} \mathbf{y}, \quad \boldsymbol{\delta}_{\mathbf{d}}=\left(\mathbf{X}^{\mathbf{T}} \mathbf{X}\right)^{-\mathbf{1}} \mathbf{X}^{\mathbf{T}} \mathbf{W} \mathbf{y}, \\
\sigma^{2}=\frac{\left\{\left(\mathbf{e}_{\mathbf{0}}-\rho \mathbf{e}_{\mathbf{d}}\right)^{\mathbf{T}}\left(\mathbf{e}_{\mathbf{0}}-\rho \mathbf{e}_{\mathbf{d}}\right)\right\}}{\mathrm{n}} .
\end{gathered}
$$




\section{STUDI KASUS}

Data yang digunakan pada penelitian ini berupa data sekunder berupa data indek pembangunan manusia seluruh provinsi di Indonesia pada tahun 2016 dan faktor-faktor yang mempengaruhinya. Data ini diperoleh dari Badan Pusat Statistik (BPS) di Indonesia pada tahun 2016, terdiri 34 Provinsi di Indonesia. Peta provinsi di Indonesia tahun 2016 disajikan pada Gambar 2.

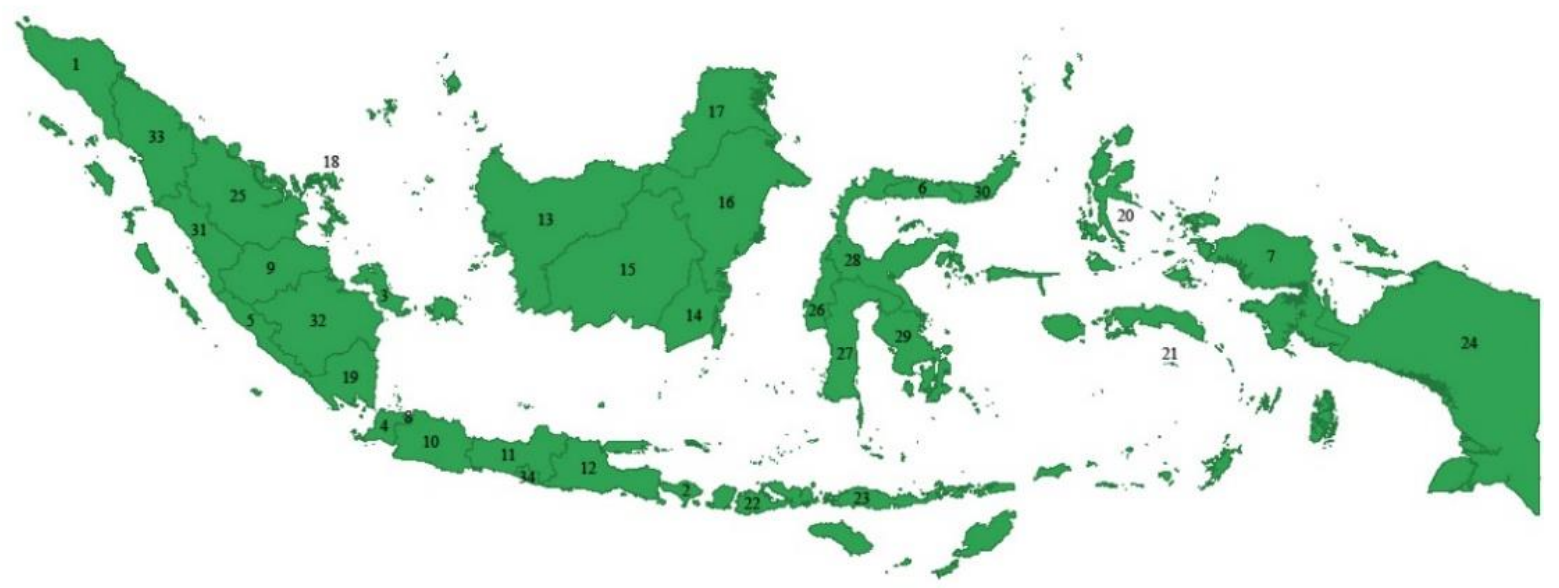

Sumber: OpenGeoda (Olahan)

Gambar 2 Peta Tematik Seluruh Provinsi di Indonesia

Pada Gambar 2 menggambarkan tentang letak 34 provinsi di Indonesia yang ditulis berdasarkan urutan 1-34 pada aplikasi OpenGeoda. Urutan tersebut menjelaskan nama-nama untuk setiap provinsi. Matriks pembobot spasial berukuran $34 \times 34$ dengan $i$ dan $j$ yang merupakan baris dan kolom. Baris dan kolom pada elemen matriks terdiri dari nama-nama provinsi yang terdapat di Indonesia. Hasil pemberian bobot pada 34 provinsi berdasarkan peta provinsi di Indonesia dengan metode Queen Contiguity disajikan pada Gambar 3.

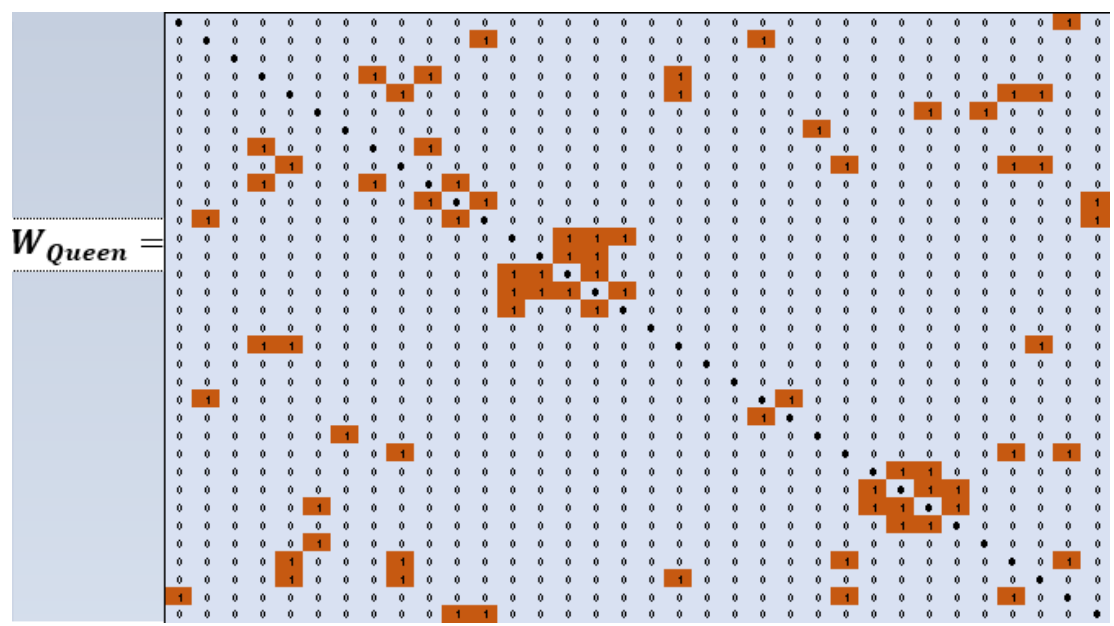

Gambar 3 Matriks Pembobot dengan Metode Queen Contiguity ( $\left.W_{\text {Queen }}\right)$

Bobot untuk masing-masing provinsi dihitung sesuai dengan banyaknya jumlah ketetanggaan dari provinsi tersebut. Dari matriks pembobot dapat dilakukan standarisasi agar setiap baris memiliki jumlah bobot sama dengan 1, sehingga masing-masing provinsi yang diamati memiliki bobot yang sama rata terhadap tetangga provinsi terdekat dan memiliki nilai 0 jika tidak bertetanggaan. Matriks Queen Contiguity yang sudah distandarisasi disajikan pada Gambar 4. 


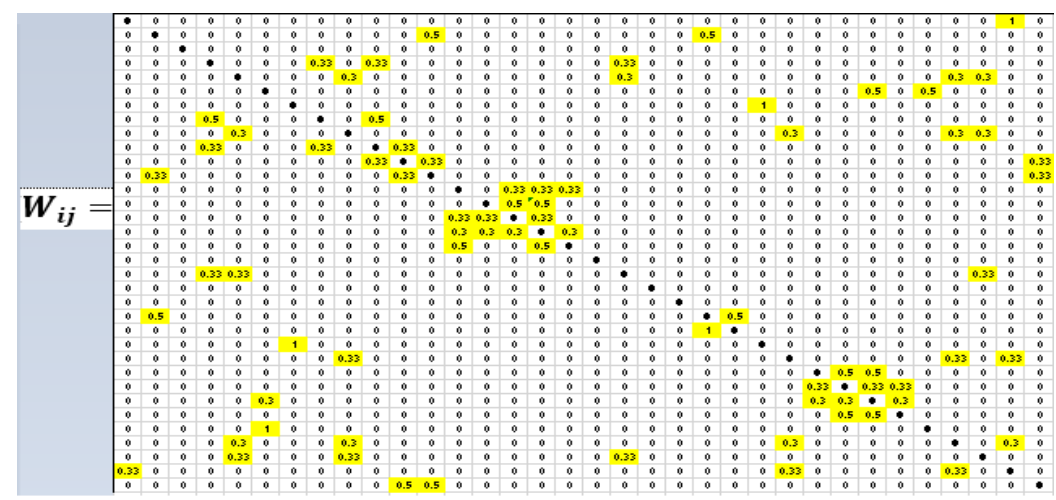

Gambar 4 Matriks Pembobot Terstandarisasi $\left(W_{i j}=\right)$

\section{PENGUJIAN DEPENDENSI LAG SPASIAL}

Rentang nilai dari Moran's I pada matriks pembobot spasial terstandarisasi adalah antara $-1 \leq I \leq 1$. Apabila $-1 \leq I<0$ maka data menunjukkan adanya autokorelasi spasial negatif. Jika $0<I \leq 1$ maka data menunjukkan adanya autokorelasi spasial positif, sedangkan jika nilai Moran's I sama dengan nol, maka tidak terdapat autokorelasi spasial. Untuk mengidentifikasi adanya autokorelasi spasial atau tidak, dilakukan uji signifikansi Moran's I. Hasil dari statistik uji Moran's I untuk setiap variabel akan disajikan pada Tabel 1.

Tabel 1 Nilai Indeks Moran

\begin{tabular}{|c|l|c|c|}
\hline Variabel & \multicolumn{1}{|c|}{ Keterangan } & Moran's I & Z-hitung \\
\hline $\mathrm{Y}$ & Persentase indeks pembangunan manusia & 0,3884 & 3,5780 \\
\hline $\mathrm{X}_{1}$ & Persentase angka harapan hidup & 0,5178 & 4,683 \\
\hline $\mathrm{X}_{2}$ & Persentase hidup lama sekolah & 0,1737 & 1,7433 \\
\hline $\mathrm{X}_{3}$ & Persentase angka melek huruf & 0,1580 & 1,6093 \\
\hline $\mathrm{X}_{4}$ & Persentase rumah tangga kumuh perkotaan & 0,2843 & 2,6886 \\
\hline $\mathrm{X}_{5}$ & Persentase tenaga kerja formal & 0,3892 & 3,5845 \\
\hline
\end{tabular}

Berdasarkan Tabel 1 dapat dilihat nilai Moran's I untuk variabel dependen $\mathrm{Y}$ dan variabel independen $\mathrm{X}_{1}, \mathrm{X}_{2}, \mathrm{X}_{3}, \mathrm{X}_{4}$, dan $\mathrm{X}_{5}$ terletak diantara 0 dan 1 , hal ini menunjukkan bahwa adanya autokorelasi spasial positif pada data tersebut. Diketahui nilai $Z_{\text {hitung }}>Z_{\text {tabel }}$ untuk 3 variabel independen yang mengandung autokorelasi positif dan 2 variabel independen yang mengandung autokorelasi negatif. Dapat diambil keputusan untuk menolak $H_{0}$ pada taraf signifikansi $\alpha=5 \%, Z_{\text {tabel }}=$ $\mathrm{Z}_{(0,025)}=1,96$ dan disimpulkan bahwa data mengandung autokorelasi spasial pada variabel dependen dan variabel independen.

Selanjutnya di estimasi dengan metode kuadrat terkecil (OLS) untuk mencari faktor-faktor yang paling signifikan terhadap IPM. Nilai parameter OLS untuk variabel yang signifikan disajikan pada Tabel 2.

Tabel 2 Nilai Parame ter OLS untuk Variabel yang Signifikan

\begin{tabular}{|c|c|c|c|c|c|}
\hline Variabel & Koefisien & Std. Error & T hitung & T table & Signifikansi \\
\hline Konstanta & $-17,704$ & 8,837 & $-2,003$ & & 0,055 \\
\hline$X_{1}$ & 0,636 & 0,135 & 4,717 & \multirow{4}{*}{2,0452} & $5,57 \mathrm{E}-05$ \\
\hline$X_{2}$ & 1,879 & 0,411 & 4,575 & $8,24 \mathrm{E}-05$ \\
\hline$X_{3}$ & 0,129 & 0,060 & 2,137 & & 0,041 \\
\hline$X_{5}$ & 0,154 & 0,032 & 4,793 & & $4,51 \mathrm{E}-05$ \\
\hline
\end{tabular}

taraf signifikan yang digunakan $\alpha=5 \%$, sehingga diperoleh $\mathrm{T}_{(0,025 ; 29)}=2,0452, R^{2}=86,92 \%$. 
Berdasarkan Tabel 2 dapat dilihat bahwa terdapat empat variabel independen yang berpengaruh secara signifikan terhadap variabel dependen. Variabel tersebut adalah persentase angka harapan hidup $\left(\mathrm{X}_{1}\right)$, persentase hidup lama sekolah $\left(\mathrm{X}_{2}\right)$, persentase angka melek huruf $\left(\mathrm{X}_{3}\right)$, dan persentase tenaga kerja formal $\left(\mathrm{X}_{5}\right)$, karena memiliki nilai $T_{\text {hitung }}>\mathrm{T}_{0,025 ; 29}$ atau nilai signifikannya $<0,05$. Dari hasil analisis data didapatkan nilai adalah $86,92 \%$, hal ini berarti bahwa model yang terbentuk mewakili data sebesar 86,92\%. Dari Tabel 2 diperoleh model persamaan regresi linier berganda yaitu:

$$
\widehat{Y}=-17,704+0,636 X_{1}+1,879 X_{2}+0,129 X_{3}+0,154 X_{5} .
$$

\section{PENGUJIAN LAG SPASIAL DENGAN LM}

Untuk mengidentifikasi adanya dependensi lag spasial pada variabel dependen, dilakukan uji signifikansi LM lag. Tingkat signifikansi : $\alpha=5 \%$ dan $\chi_{(1 ; 0,95)}^{2}=0,004$

$$
L M_{\text {lag }}=\frac{\left(\boldsymbol{\varepsilon}^{\mathbf{T}} \mathbf{W Y}\right)^{2}}{\mathrm{~s}^{2}\left((\mathbf{W X} \boldsymbol{\beta})^{\mathbf{T}} \mathbf{M}(\mathbf{W X} \boldsymbol{\beta})+\mathrm{Ts}^{2}\right)}=0,13419642 .
$$

Berdasarkan perhitungan statistik uji diperoleh nilai $L M_{\text {lag(y) }}=0,13419642$ dan lebih besar dari nilai tabel chi-square. Sesuai dengan kriteria pengujian maka dapat diambil keputusan untuk menerima $H_{0}$ karena $L M_{\text {lag }}>\chi_{(1 ; 0,95)}^{2}$ yang berarti terdapat dependensi lag spasial pada variabel dependen.

\section{ESTIMASI MODEL SAR DENGAN MAXIMUM LIKELIHOOD}

Berdasarkan hasil identifikasi dengan nilai Indeks Moran untuk setiap variabel, menunjukkan bahwa dependensi antarlokasi yang berdekatan (autokorelasi spasial) terjadi pada variabel dependen dan variabel independen. Selanjutnya pada pengujian dependensi lag spasial dengan LM untuk variabel yang signifikan teridentifikasi autokorelasi spasial, dan diketahui terdapat dependensi lag spasial pada variabel dependen dan variabel independen. Oleh karena itu dilakukan analisis dengan model SAR. Hasil estimasi parameter model SAR dengan maximum likelihood disajikan pada Tabel 3.

Tabel 3 Nilai Estimasi Parame ter SAR

Dari Tabel 3, diperoleh model SAR adalah:

\begin{tabular}{|c|c|c|}
\hline Parameter & Estimasi & Wald \\
\hline$\rho$ & $-0,021$ & 640,89 \\
\hline $\boldsymbol{\beta}_{\mathbf{0}}$ & $-19,86$ & $-91,68$ \\
\hline $\boldsymbol{\beta}_{\mathbf{1}}$ & 0,636 & 0,208 \\
\hline $\boldsymbol{\beta}_{\mathbf{2}}$ & 1,879 & $-0,730$ \\
\hline $\boldsymbol{\beta}_{\mathbf{3}}$ & 0,129 & $-0,026$ \\
\hline $\boldsymbol{\beta}_{\mathbf{5}}$ & 0,154 & $-0,086$ \\
\hline$R^{2}$ & \multicolumn{2}{|c|}{$87,26 \%$} \\
\hline
\end{tabular}

$$
\widehat{\mathrm{Y}}_{\mathrm{i}}=-0,021 \mathrm{~W}_{1} \mathrm{Y}_{\mathrm{i}}-17,70+0,636 \mathrm{X}_{1}+1,879 \mathrm{X}_{2}+0,129 \mathrm{X}_{3}+0,154 \mathrm{X}_{5}
$$

Hasil estimasi menunjukkan bahwa terdapat dependensi lag spasial yaitu pengaruh letak provinsi yang berdekatan dengan provinsi yang diamati pada variabel presentase indeks pembangunan manusia (Y). Hal ini ditunjukkan oleh nilai parameter $\rho$, yaitu lag variabel dependen yang berpengaruh signifikan, karena nilai Wald pada $\rho>\chi_{(1 ; 0,95)}^{2}=3,481$. Pada model SAR yang dihasilkan, pembobot $\mathbf{W}_{\mathbf{1}}$ menunjukkan adanya pengaruh letak provinsi yang berdekatan $(j)$ dengan provinsi yang diamati $(i)$ terhadap persentase indeks pembangunan manusia.

Model SAR pada Persamaan(1) dapat diinterpretasikan, bahwa apabila faktor lain dianggap konstan maka apabila variabel persentase angka harapan hidup $\left(\mathrm{X}_{1}\right)$ meningkat sebesar 1 satuan, maka dapat menambah persentase indeks pembangunan manusia sebesar 0,636. Apabila variabel persentase hidup lama sekolah $\left(\mathrm{X}_{2}\right)$ meningkat sebesar 1 satuan, maka dapat menambah persentase indeks pembangunan 
manusia sebesar 1,879. Apabila variabel persentase angka melek huruf $\left(\mathrm{X}_{3}\right)$ meningkat sebesar 1 satuan, maka dapat menambah persentase indeks pembangunan manusia sebesar 0,129. Apabila variabel persentase tenaga kerja formal $\left(\mathrm{X}_{5}\right)$ meningkat sebesar 1 satuan, maka dapat menambah persentase indeks pembangunan manusia sebesar 0,154 .

Pada Tabel 3 menunjukkan bahwa terdapat variabel independen yang berpengaruh signifikan dengan adanya pembobot. Terdapat variabel yang berpengaruh signifikan tanpa adanya pembobot pada $\alpha=5 \%$ yaitu variabel persentase angka harapan hidup $\left(X_{1}\right)$, variabel persentase hidup lama sekolah $\left(\mathrm{X}_{2}\right)$, variabel persentase angka melek huruf $\left(\mathrm{X}_{3}\right)$, dan variabel persentase tenaga kerja formal $\left(\mathrm{X}_{5}\right)$.

Pemilihan model terbaik menggunakan kriteria nilai AIC dan $R^{2}$ untuk beberapa ketergantungan faktor IPM. Model yang terbaik adalah model yang memiliki nilai AIC yang paling kecil dan nilai $R^{2}$ terbesar. Dengan cara meregresikan semua variabel independen $X$ yang signifikan yaitu $X_{1}, X_{2}, X_{3}$, dan $\mathrm{X}_{5}$ terhadap variabel dependen $\mathrm{Y}$, sehingga didapat 15 kombinasi variabel independen. Hasil disajikan pada Tabel 4.

Tabel 4 Nilai AIC dan $\boldsymbol{R}^{2}$ untuk Pemilihan Model Terbaik

\begin{tabular}{|c|c|c|}
\hline Variabel & AIC & $\boldsymbol{R}^{\mathbf{2}}$ \\
\hline $\mathbf{Y}, \mathbf{X}_{\mathbf{1}}$ & 164,036 & $63,45 \%$ \\
\hline $\mathbf{Y}, \mathbf{X}_{\mathbf{2}}$ & 185,569 & $31,15 \%$ \\
\hline $\mathbf{Y}, \mathbf{X}_{\mathbf{3}}$ & 186,48 & $29,27 \%$ \\
\hline $\mathbf{Y}, \mathbf{X}_{\mathbf{5}}$ & 177,899 & $45,04 \%$ \\
\hline $\mathbf{Y}, \mathbf{X}_{\mathbf{1}}, \mathbf{X}_{\mathbf{2}}$ & 155,3 & $73,34 \%$ \\
\hline $\mathbf{Y}, \mathbf{X}_{\mathbf{1}}, \mathbf{X}_{\mathbf{3}}$ & 154,956 & $73,62 \%$ \\
\hline $\mathbf{Y}, \mathbf{X}_{\mathbf{1}}, \mathbf{X}_{\mathbf{5}}$ & 158,993 & $70,29 \%$ \\
\hline $\mathbf{Y}, \mathbf{X}_{\mathbf{2}}, \mathbf{X}_{\mathbf{3}}$ & 182,077 & $41,41 \%$ \\
\hline
\end{tabular}

\begin{tabular}{|c|c|c|}
\hline Variabel & AIC & $\boldsymbol{R}^{\mathbf{2}}$ \\
\hline $\mathbf{Y}, \mathbf{X}_{\mathbf{2}}, \mathbf{X}_{\mathbf{5}}$ & 153,157 & $74,97 \%$ \\
\hline $\mathbf{Y}, \mathbf{X}_{\mathbf{3}}, \mathbf{X}_{\mathbf{5}}$ & 169,12 & $59,97 \%$ \\
\hline $\mathbf{Y}, \mathbf{X}_{\mathbf{1}}, \mathbf{X}_{\mathbf{2}}, \mathbf{X}_{\mathbf{3}}$ & 150,921 & $77,91 \%$ \\
\hline $\mathbf{Y}, \mathbf{X}_{\mathbf{1}}, \mathbf{X}_{\mathbf{2}}, \mathbf{X}_{\mathbf{5}}$ & 137,611 & $85,06 \%$ \\
\hline $\mathbf{Y}, \mathbf{X}_{\mathbf{1}}, \mathbf{X}_{\mathbf{3}}, \mathbf{X}_{\mathbf{5}}$ & 149,07 & $79,08 \%$ \\
\hline $\mathbf{Y}, \mathbf{X}_{\mathbf{2}}, \mathbf{X}_{\mathbf{3}}, \mathbf{X}_{\mathbf{5}}$ & 151,743 & $77,36 \%$ \\
\hline $\mathbf{Y}, \mathbf{X}_{\mathbf{1}}, \mathbf{X}_{\mathbf{2}}, \mathbf{X}_{\mathbf{3}}, \mathbf{X}_{\mathbf{5}}$ & 134,189 & $87,26 \%$ \\
\hline
\end{tabular}

Berdasarkan Tabel 4 pada penaksiran kasus indeks pembangunan manusia seluruh provinsi di Indonesia pada tahun 2016 diperoleh nilai AIC paling kecil sebesar 134,189 dengan nilai $R^{2}$ sebesar $87,26 \%$. Hal ini berarti IPM dipengaruhi oleh $\mathrm{X}_{1}, \mathrm{X}_{2}, \mathrm{X}_{3}$, dan $\mathrm{X}_{5}$

\section{PENUTUP}

Berdasarkan hasil analisis dan pembahasan yang telah dilakukan, maka dapat diperoleh beberapa kesimpulan, yaitu sebagai berikut:

1. Pada kasus indeks pembangunan manusia seluruh provinsi di Indonesia pada tahun 2016, terdapat ketergantungan spasial antardaerah dan adanya heterogenitas spasial antardaerah, sehingga dapat dimodelkan regresi spasial yaitu SAR.

2. Model SAR yang terbentuk untuk memodelkan kasus indeks pembangunan manusia seluruh provinsi di Indonesia pada tahun 2016 adalah sebagai berikut:

$$
\widehat{\mathrm{Y}}_{\mathrm{i}}=-0,021 \mathrm{~W}_{1} \mathrm{Y}_{\mathrm{i}}-17,70+0,636 \mathrm{X}_{1}+1,879 \mathrm{X}_{2}+0,129 \mathrm{X}_{3}+0,154 \mathrm{X}_{5} .
$$

Pada persamaan model yang telah diperoleh untuk masing-masing jumlah tetangga tersebut, menunjukkan bahwa semakin banyak jumlah tetangga pada suatu provinsi maka semakin kecil nilai koefisien dependensi lag spasial untuk variabel dependen. Hal ini menunjukkan bahwa banyaknya jumlah tetangga sangat berpengaruh terhadap nilai estimasi persentase indeks pembangunan manusia seluruh provinsi di Indonesia pada tahun 2016.

\section{DAFTAR PUSTAKA}

[1] Nugroho, Adi. 2017. Indeks Pembangunan Manusia 2016. Badan Pusat Statistik: CV Nario Sari. ISSN: 2086-2369 
[2] Algifari. 2013. Analisis Regresi: Teori, Kasus, dan Solusi Edidi Kedua Cetakan ke-4. DPFE: Yoyakarta.

[3] Arbia, G. 2006. Spatial Econometrics: Statistical Foundations and Applications to Regional Convergence. Berlin: Springer.

[4] LeSage, J. and Pace, R. 2009. Intorduction to Spatial Econometrics.New York: CRC Press.

[5] Tiro, Muhammad Arif. 2010. Analisis Korelasi dan Regresi Edisi Ketiga. Andi Publisher: Makassar.

[6] Rati, M. 2013. Model Regresi Spasial untuk Anak Tidak Bersekolah Kurang 15 Tahun di Kota Medan. Universitas Sumatera Utara: Medan.

[7] Bekti, R.D dan Sutikno. 2011. Spatial Durbin Model to Identify Influential Factors of Diarrhea. Jurnal of Mathematics and Statistics. Institut Teknologi Sepuluh November: Surabaya.

[8] Kosfeld, R. 2006. Spatial Econometric. http://www.scribd.com, [Diakses pada tanggal 23 Desember 2015].

[9] Anselin, L. 1988. Spatial Econometrics: methods and models. Dordrecht: Kluwer Academic Publishers.

[10] Rencher, A.C. and Schaalje, G.B. 2008. Linier Model in Statistics, Second Edition. New York: John Willey \& Sons.

[11] Sutarman. 2013. Konsep dan Aplikasi Matematika Matriks. FMIPA USU:Medan.

[12] Shresta Man, Prasanna. 2006. A Document Submited to the Faculty of Graduate Studies., [Diakses pada tanggal 16 Agustus 2015].

[13] Ramadani, I.R, Rita. R dan Abdul. H. 2013. Analisis Faktor-Faktor yang Mempengaruhi Gizi Buruk Balita di Jawa Tengah dengan Metode Spatial Durbin Model. Jurnal Gaussian; 2(4):333-342

HENNY PRIANDINI AMALIA : Universitas Tanjungpura, Jl. Prof. Dr. H. Hadari Nawawi, hennypriandiniamalia25@student.untan.ac.id

YUNDARI

HELMI
: Universitas Tanjungpura, Jl. Prof. Dr. H. Hadari Nawawi, yundari@math.untan.ac.id

: Universitas Tanjungpura, Jl. Prof. Dr. H. Hadari Nawaawi, helmi132205@yahoo.co.id 
